\title{
Deconstruction-Critical Thinking: Alternative Learning Model of Literature Appreciation in Industrial Revolution 4.0
}

\author{
Sri Sulistiani* \\ Universitas Negeri Surabaya \\ Surabaya, Indonesia \\ srisulistiani@unesa.ac.id
}

\author{
Setya Yuwana Sudikan \\ Universitas Negeri Surabaya \\ Surabaya, Indonesia \\ setyayuwana@unesa.ac.id.
}

\begin{abstract}
Deconstruction-critical thinking is an effort to develop a creative Literature Appreciation learning model. All deconstruction is critical, but everyone's critical is different and not all perfect. This model is the result of Derrida's deconstruction fiction with critical thinking of the Facione Model. Deconstruction-critical is carried out to find something new that is contradictory by dismantling text based on language instability, phonocentrism-logocentrism, and metaphors, it is necessary to bring up new meanings and meanings through the interpretation of activity, analysis, inference, discussion, discussion, consideration, and selfdelivery. The focus of the article's problem is "how the conceptual basis of deconstruction-critical" and "how to implement deconstruction-critical in Literature Appreciation learning class". Deconstruction-critical learning models that are expected to overcome boredom and support learning of critical and creative Literary Appreciation learning and provide insights about the teacher can develop continuously developing learning models for their classes.
\end{abstract}

Keywords - development, models, learning, deconstructioncritical, literature appreciation

\section{INTRODUCTION}

In the era of the industrial revolution (RI) 4.0, an important challenge in the world of education was developing quality and competitive human resources in an environment of super modern society that was characterized by data literacy, technological literacy, and human resource literacy. The development of digital technology is extremely fast and influences a person to get data and information easily and quickly without any time and space limit. Humans are required to be independent individuals who can communicate, collaborate, think critically, creatively, and innovatively. Human literacy is important so that humans can survive, function, and can understand complex interactions in all contexts or environments.

This research will integrate Derrida's deconstruction with critical thinking of the Facione model. Deconstruction is interpreted as an attempt to rearrange or an unusual form of structure. The meaning of deconstruction refers to a person's actions in dismantling an object with its constituent components which are indeed worthy of being dismantled. Deconstruction shows that every text is always present as a social construction that is contextual and contains the historical value. These assumptions can be traced to its formation in history that Derrida's deconstruction actually emerged as a critique of the Susserian theory which formulated his theory through the existence of binary opposition such as langue-parole, utterance, non-existent, pure-polluted, which means the first is more superior and second tend to be inferior, so as if the first has the privilege while the second is abused Deconstruction rejects the establishment or rigidity and absolutism of structuralism theories which he calls grand-theory. In criticizing Saussure's theory, Derrida offers a method of differentiation or difference in getting meaning. The term differentiation contains destructive power for the level of markers and is immune from all forms of reduction, because differentiation gives rise to a distance that will always exist between the marker and also between the text and its meaning. Derrida's deconstruction of thought to release the text from its context in this study focused on language instability, phonocentrism and logocentrism, and metaphors (Sarup, 1993, p. 32-38; 2008, p. 46).

Deconstruction thinking must be based on critical thinking. Critical thinking is the development of cognitive domains in Bloom's taxonomy on C-4 (analytical-synthesis), C-5 (evaluation), and C-6 (re-creation / creating) high-level skills and 21 st-century skills that cover $4 \mathrm{C}$, namely creative, critical thinking, collaborative, and communicative. Many experts express their opinions on critical thinking, one of which is Facione (1990a; Dileklii, 2017, p. 70-71) who divides critical thinking into six components, namely interpretation, analysis, inference, explanation, evaluation, and self-regulation. Critical thinking denies one's caution and ability to draw conclusions to distinguish between active, persistent, creative in considering something knowledge with the support of responsible and trustworthy truth (Rahimi \& Sajed, 2014, p. 43).

This article tries to integrate Derrida's deconstruction thinking with critical thinking of the Facione Model that the author's knowledge has never been done. This integration gave birth to the elements of deconstruction-critical thinking which became the basis for the development of the steps of learning that were intended to be trialed in the process of learning literary appreciation. For this reason, the discussion in this article focuses on the conceptual thinking of deconstruction-critical and class syntax with the model.

\section{METHOD}

This article is a research prototype of developing a deconstruction-critical model in literary appreciation learning. Deconstruction-critical conceptual data was collected by studying literature documentation to build theoretical traditions that integrate derrida's deconstruction thinking with critical thinking of the facione model. Data analysis was performed during and after data collection and 
presented descriptively. Measurement of data reliability is done by triangulating sources, methods, and other data, so that accurate and reliable data is obtained. The results of data analysis about deconstruction-critical thinking are used as the basic framework of the steps or syntax of the learning model that will be developed in the literature appreciation learning class.

\section{RESULTS AND DISCUSSION}

The learning model is a procedure or reference that is made systematically to organize learning experiences to be more directed to achieve the goals to be achieved. The development of learning models is part of the main task of lecturers/teachers in managing learning in their classrooms. One of the characteristics of the learning model that is developed must have a syntax or clear learning steps in managing learning in the classroom.

\section{A. RESULTS}

The term deconstruction is used by Derrida as a form of radicalization of critical text reading so that it can capture meaning in different ways for people who read it and at the same time provide different interpretations based on logic or new thinking. Derrida began by analyzing the relationship between language, speech, and writing. In the history of deconstruction, his thoughts are outlined in 3 very influential books, namely Of Grammatology, Speech and Phenomena, and Writing and Difference. All three books criticized the phenomenology-Husserl, linguistics-Saussurean, psychoanalysis-Lacanan, and structuralism-Levi Strauss.

Royle (2003, p. 40) explains that what needs to be understood about Derrida is the destruction of key ideas until finally realizing there are no more 'key ideas'. Deconstruction would not make sense without a structure that can be damaged. Deconstruction is an earthquake that shakes the entire text and turns it in an entirely unexpected direction that is often contradictory.

Derrida's deconstruction is actually a useful practice in uncovering hidden meanings and perceptions in the text in a style of interpretation to find out unexpected meanings. The author does have the ability to express ideas and ideas in written form, but how the text is understood readers have the freedom to interpret based on the experience they have. Derrida wants to show that in interpreting the text in addition to taking into account the 'key ideas' of the author, it also considers 'supplements' as the development of meaning that is influenced by the reader's experience. Deconstruction is indeed aimed at uncovering other hidden and implied meanings, not to show the meaning of explicit texts.

For Al-Fayyad (2005, p. 8), deconstruction moves beyond traditional dogmatism or naive nihilism. In connection with the constructive philosophical task, the deconstruction reminds us that every construction of language and text cannot avoid the metaphorical and intertextual character. The truth which is compiled in the end cannot be singular and so vulnerable to changes in interpretation. In the end, deconstruction researchers accept all the main sections as readers, translators, examiners, investigators, evaluators, and critics, at different points.

Deconstruction is one of the results of critical thinking. Critical thinking is very important, but in reality, many highly educated and intelligent people have difficulty thinking critically. In this article choose the Facione critical thinking model (2011; Hussin, et.al. 2019, p. 6) because of its focus on testing critical thinking skills in a group interactive learning environment. This model suggests 6 skills which include: (1) Interpretation which means categorization, decomposition of important meanings, and expressing various events, experiences, beliefs, judgments, procedures, and criteria; (2) Analysis which means exploring ideas, identifying and analyzing arguments; (3) Inference which means finding the elements needed to form a hypothesis, make conclusions, reflect on relevant information and infer the consequences that flow from data, evidence, statements, beliefs, questions, and alternative speculations; (4) Evaluation which means assessing the level of trust in a statement which is a description of one's experience, perception, judgment in assessing the logical power of the actual inferential relationship between statements and other forms of representation; (5) Explanation means confirming results, validating procedures and describing arguments; and (6) Self-regulation means selfcorrection and self-examination.

The Facione model was chosen because it has a clear concept and these concepts are also partly found in the thoughts of other experts. The results of theoretical studies show that "all deconstruction is critical", but what needs to be studied further is that critical thinking has not reached all elements perfectly but there must be weaknesses. Critical thinking of each person varies according to their respective competencies. The success of the learning process with this critical deconstruction thinking model will be influenced by several other factors, such as age, gender, learning styles and teaching in general school education (Dileklii, 2017, p. 70). This critical thinking becomes a liberating force and a strong resource for students to innovate in education.

This study places deconstruction as a thinking model by integrating Derrida's deconstruction with critical thinking of the Facione model. The integration of Derrida's deconstruction with the critical thinking of the Facione model is illustrated below. The building blocks of the two concepts are integrated to produce new concepts.

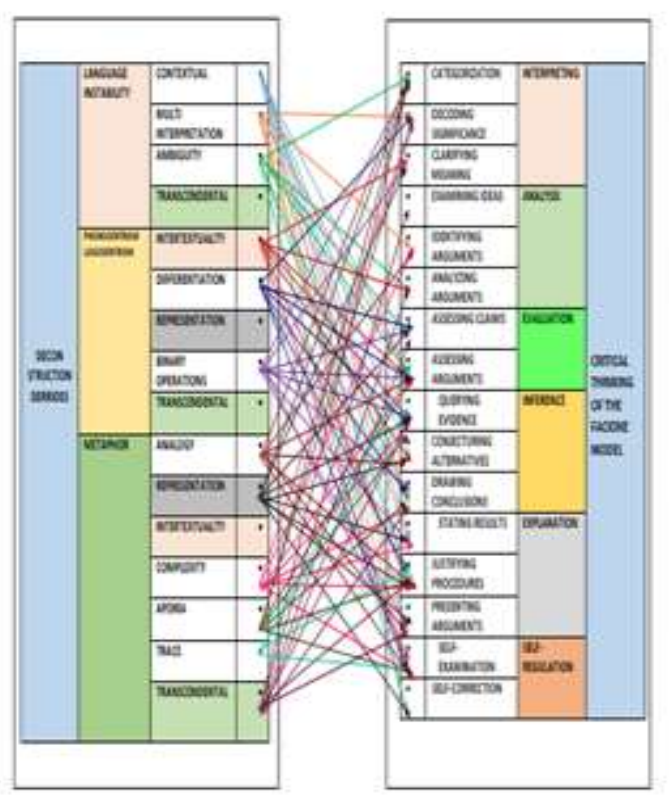


Figure 01: Integration of Derrida's Deconstruction and Facione Model Critical Thinking

Integration is done to find the similarities and differences of the elements. The different elements that do not show equality are what are called "deconstruction-critical" thinking.

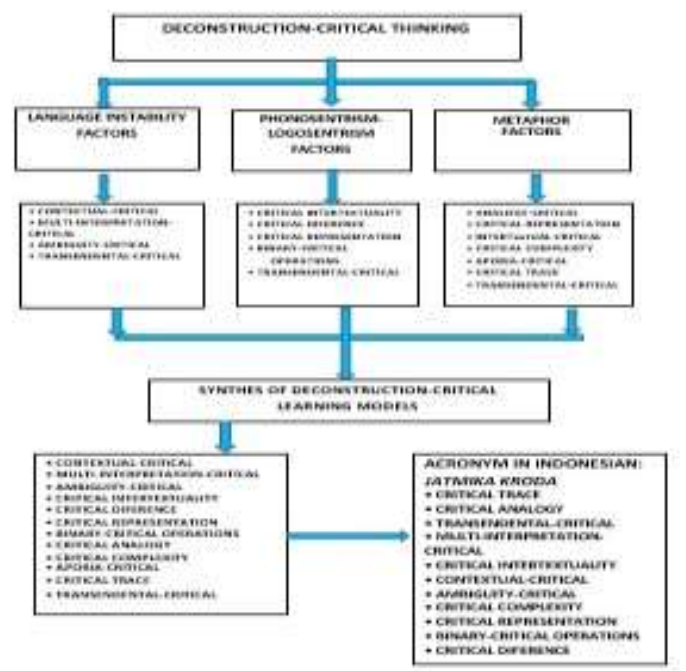

Figure 02: Derrida Deconstruction Intersection and Critical Model Facione Thinking

Intersection of Derrida's deconstruction concept with critical thinking of the Facione model results in 12 steps of deconstruction-critical thinking that is synchronized with "JATMIKA-KRODA" to facilitate remembering. The twelve steps of thinking are used as a basis for developing a step model or learning syntax. The learning syntax is then applied by modifying the design phase of Gordon's Synectic model development (Joyce,et.al, 2009, p. 243-277; Nuryatin \& Irawati, 2016, p. 106-110) which includes syntmatics, social systems, roles and tasks of lecturers / teachers, support systems, and the impact of learning and accompaniment.

\begin{tabular}{|l|l|}
\hline $\begin{array}{l}\text { The Design Phase of } \\
\text { the Model } \\
\text { Development }\end{array}$ & $\begin{array}{l}\text { Steps for } \\
\text { Deconstruction } \\
\text { \& Description }\end{array}$ \\
\hline $\begin{array}{l}\text { Syntactic } \\
\text { "JATMIKA- }\end{array}$ & $\begin{array}{l}\text { Learning is based on the } \\
\text { concept of psychology of } \\
\text { learning nativism that students } \\
\text { have basic talents or abilities } \\
\text { and scientific thinking } \\
\text { processes. }\end{array}$ \\
\hline Critical-Trace & $\begin{array}{l}\text { Learners do the initial activity } \\
\text { by 'observing" literary works } \\
\text { and tracking to find traces of } \\
\text { signs in the text that are } \\
\text { influenced by critical thinking } \\
\text { and curiosity with the activity of } \\
\text { "asking" which is arranging } \\
\text { hook questions as the basis of } \\
\text { the learning process This } \\
\text { activity is influenced by } \\
\text { assessment arguments, proof of } \\
\text { questions, adjustment } \\
\text { procedures, and self-assessment. }\end{array}$ \\
\hline \begin{tabular}{l} 
Learners make a comparison of \\
\hline
\end{tabular}
\end{tabular}

\begin{tabular}{|c|c|}
\hline & $\begin{array}{l}\text { similarities about the text with } \\
\text { other texts that are influenced } \\
\text { by categorization, identification, } \\
\text { alternative allegations, } \\
\text { adjustment procedures, current } \\
\text { arguments, and self-assessment. }\end{array}$ \\
\hline $\begin{array}{l}\text { - Transcendental- } \\
\text { Critical }\end{array}$ & $\begin{array}{l}\text { Learners do an analysis by } \\
\text { thinking about something } \\
\text { abstract, magical, transcendent } \\
\text { or metaphysical about texts that } \\
\text { are influenced by } \\
\text { categorization, examination } \\
\text { ideas, analysis of arguments, } \\
\text { claims assessment, proof of } \\
\text { questions, drawing conclusions, } \\
\text { adjusting procedures, and } \\
\text { current arguments. }\end{array}$ \\
\hline $\begin{array}{l}\text { - Multi-Critical } \\
\text { Interpretation }\end{array}$ & $\begin{array}{l}\text { Learners carry out multiple } \\
\text { interpretations of the analysis of } \\
\text { objects that are affected by the } \\
\text { decoding of meaning, } \\
\text { identification of arguments, } \\
\text { assessment arguments, } \\
\text { concluding, statement of results, } \\
\text { current arguments, and self- } \\
\text { assessment. }\end{array}$ \\
\hline $\begin{array}{l}\text { - Intertextual- } \\
\text { Critical }\end{array}$ & $\begin{array}{l}\text { Learners conduct an analysis of } \\
\text { the intertwining of texts with } \\
\text { other texts carried out with } \\
\text { clarification of meaning, } \\
\text { analysis of arguments, } \\
\text { assessment arguments, proof of } \\
\text { questions, alternative } \\
\text { allegations, adjustment } \\
\text { procedures, and self-assessment. }\end{array}$ \\
\hline $\begin{array}{l}\text { - Contextual- } \\
\text { Critical }\end{array}$ & $\begin{array}{l}\text { Learners conduct an analysis of } \\
\text { the context or environment that } \\
\text { is influenced by assessment } \\
\text { arguments, alternative } \\
\text { allegations, drawing } \\
\text { conclusions, statement of } \\
\text { results, adjustment procedures, } \\
\text { current arguments, and self- } \\
\text { correction. }\end{array}$ \\
\hline $\begin{array}{l}\text { Critical- } \\
\text { Ambiguity }\end{array}$ & $\begin{array}{l}\text { Learners do an analysis of the } \\
\text { ambiguity resulting from } \\
\text { multiple interpretations } \\
\text { influenced by categorization, } \\
\text { analysis of arguments, claims } \\
\text { and evaluation arguments, } \\
\text { drawing conclusions, } \\
\text { adjustment procedures, and self- } \\
\text { correction. }\end{array}$ \\
\hline $\begin{array}{l}\text { - Critical- } \\
\text { complexity }\end{array}$ & $\begin{array}{l}\text { Learners conduct an analysis } \\
\text { relating to the complexity of } \\
\text { something that is affected by the } \\
\text { decoding of meaning, } \\
\text { identification of arguments, } \\
\text { assessment arguments, proof of } \\
\text { questions, drawing conclusions, } \\
\text { statement of results, adjustment }\end{array}$ \\
\hline
\end{tabular}




\begin{tabular}{|c|c|}
\hline & procedures, and self-assessment \\
\hline $\begin{array}{l}\text { - Critical- } \\
\text { Representation }\end{array}$ & $\begin{array}{l}\text { Learners carry out the process } \\
\text { of re-defining an object, reality, } \\
\text { or phenomenon influenced by } \\
\text { categorization, clarification of } \\
\text { meaning, claim assessment, } \\
\text { evidence of questions, } \\
\text { alternative allegations, } \\
\text { statement of results, adjustment } \\
\text { procedures, current arguments, } \\
\text { and self-correction. }\end{array}$ \\
\hline $\begin{array}{l}\text { - Binary-Critical } \\
\text { Opposition }\end{array}$ & $\begin{array}{l}\text { Learners analyze the } \\
\text { differentiation of two } \\
\text { conflicting elements in unity } \\
\text { carried out by categorization, } \\
\text { clarification of meaning, claims } \\
\text { and assessment arguments, } \\
\text { proof of questions, conclude, } \\
\text { the results of the statement, } \\
\text { current arguments, and self- } \\
\text { assessment. }\end{array}$ \\
\hline $\begin{array}{l}\text { - Critical- } \\
\text { differentiation }\end{array}$ & $\begin{array}{l}\text { Learners analyze thinking } \\
\text { strategies to see the differences } \\
\text { that oppose the totality of } \\
\text { meaning in the text influenced } \\
\text { by the decoding of meaning, } \\
\text { claims, and assessment } \\
\text { arguments, proof of questions, } \\
\text { conclude, procedures for } \\
\text { adjustment, and self-assessment. }\end{array}$ \\
\hline - Critical-Aporia & $\begin{array}{l}\text { Learners analyze the structure } \\
\text { or logic that shows the } \\
\text { weaknesses or contradictions of } \\
\text { formal logic in the text } \\
\text { influenced by categorization, } \\
\text { decoding meaning, argument } \\
\text { assessment, question evidence, } \\
\text { drawing conclusions, } \\
\text { procedures for adjustment, and } \\
\text { self-assessment. }\end{array}$ \\
\hline 2) Social system & $\begin{array}{l}\text { This model can be done by the } \\
\text { teacher by regulating the stages } \\
\text { of learning while still opening } \\
\text { the creativity of students' } \\
\text { responses to develop ideas and } \\
\text { thoughts. }\end{array}$ \\
\hline $\begin{array}{l}\text { 3) Teacher Roles / } \\
\text { Tasks }\end{array}$ & $\begin{array}{l}\text { The teacher encourages students } \\
\text { to develop their open thinking, } \\
\text { irrationality, and critical and } \\
\text { creative expression. }\end{array}$ \\
\hline $\begin{array}{l}\text { 4) Supporting } \\
\text { System }\end{array}$ & $\begin{array}{l}\text { Learners need raw data to be } \\
\text { analyzed and analyzed. The } \\
\text { teacher's task helps learners } \\
\text { process the data in more } \\
\text { complex ways. }\end{array}$ \\
\hline $\begin{array}{l}\text { 5) Impact of } \\
\text { Learning and } \\
\text { Accompaniment }\end{array}$ & $\begin{array}{l}\text { This model is designed to train } \\
\text { students who think critically and } \\
\text { creatively. This model also } \\
\text { discusses the social environment } \\
\text { that allows students to function } \\
\text { in a metaphorical world by each }\end{array}$ \\
\hline
\end{tabular}

\section{*)JATMIKA:}

it means being calm or gentle in doing any work that is not gossipy, everything is thoughtful, so it is thoughtful and capable of any work, smart in its entirety.

*) KRODA: angry.

\section{*) Learning Class: JATMIKA class and KARTIKA class}

The integration of the two words "JATMIKA-KRODA" is interpreted as a way to manage anger in oneself to awaken the individual's potential to find positive and critical thoughts in responding, understanding, filtering values, and find conclusions from various problems encountered. The integration of these two words is very much in harmony with the concept of integration of deconstruction-critical thinking developed in this study.

\section{B. DISCUSSION}

Research on the development of learning models has been carried out by previous researchers. But so far, the authors have not found a study of deconstruction as critical thinking integration that gave birth to the syntax of learning models. Previous studies as outlined in the form of theses, theses, dissertations, and articles in journals focus on critical thinking or Derrida's deconstruction thinking alone.

Regarding Derrida's deconstruction, Yegen \& Abukan (2014, p. 48) discusses Derrida's war with the deconstruction of the conception of dominant meaning in the scope of differences, traces, decentralization, uncertainty, and metaphors to be made about modernism and postmodernism in understanding texts and meanings. The same thing was done by Hoteit (2015. p.117) whose article examines the study of philosophical currents "deconstruction" and its relationship to the architecture of deconstructivism. The results of this study explain the basic principles of philosophy that begin with Derrida's work and continue by defining the basic terms and vocabulary of this philosophy and identifying deconstruction concepts that are transferred to architecture and form the basis of architectural style of deconstructivism.

Likewise, critical thinking research also focuses on critical thinking alone as a basis for thinking that is developed, such as research conducted by Wallace \& Jefferson (2013, p. 246) which explains the results of empirical studies of the effectiveness of exercise with workbooks that can develop thinking skills in new students. Although this research data is based on a relatively small sample size, critical thinking exercises, such as those in workbooks can help develop critical thinking skills in college freshmen. In a correlational study of 30 students of the Shiraz University Azad branch, Afsahi \& Afghari (2017, p. 116) explains that there is a significant relationship between mother tongue and the level of critical thinking, but there is no significant relationship between age, gender and the level of critical thinking. Critical thinking is actually a part of daily activities, so that whenever we want to take decisions always through the process of thinking. But it must be realized that the level of severity of each person is different.

Based on the description above, there are no studies that have been written in the form of journals and dissertations that discuss deconstruction-critical. This initial research is the result of thinking to develop a learning model based on 
the thought that as an educator "must" do the development of learning models for his class so that it is not boring and at the same time maximizes the potential development of students. In this regard, the writer tries to offer deconstruction-critical thinking with the component "JATMIKA-KRODA" to be applied in the study of Literary Appreciation.

Implementation of the Syntax of "JATMIKA-KRODA" Deconstruction-Critical Learning Class Model in Literary Appreciation

The results of the integration of deconstruction-critical thinking can be applied in various fields, including learning Literary Appreciation. Literary appreciation is the activity of familiarizing and living literature seriously so as to foster understanding, appreciation, sensitivity of critical thinking, and sensitivity of good feelings towards literary creativity (Effendi, 2002, p. 6). This opinion is in line with the opinion of Oemarjati (1996, p. 58) that appreciating literature is to provide a sensitive response or understanding of literary works related to the values contained therein. Whatever forms of literary works the author creates contain values to be conveyed to the reader.

Appreciating literary behavior can occur receptively and productively. Receptive literary appreciation occurs when lovers of literature, intensive in reading, listening, and witnessing a literary performance. In this appreciation, literary works that are used as targets for receptive appreciation in the form of short stories, poetry, drama, and other literary works. While productive literature appreciation can occur when literary connoisseurs are intensive in the creative process and literary creation. In line with productive appreciation activities, a connoisseur of literature can produce literary works in various forms according to their tastes. In addition, literary appreciation is also direct and indirect. The ability to make a literary appreciation of each person is different, because each person has a different attitude to the literary work..

The results of deconstruction-critical thinking with the 12 concepts of "JATMIKA KRODA" can be applied in the form of varied learning classes, for example JATMIKA class and KARTIKA class. The acronym is used to be easy to remember and the teacher may try another set of acronyms. This effort is aligned with learning theories that students have talent, intellectual power, need the environment, and like creative procedural things. The learning class scenario is as follows.

\section{1) JATMIKA Class}

The word 'jatmika' contains the subtle meaning of being uncompromising in doing things, and intelligent in everything. The 'JATMIKA' learning core scenario has the characteristics of breaking the habit of the learning process with the following steps.

\begin{tabular}{|l|l|}
\hline $\begin{array}{c}\text { The Design Phase } \\
\text { of the Model } \\
\text { Develop-ment }\end{array}$ & \multicolumn{1}{|c|}{$\begin{array}{c}\text { Steps for Critical } \\
\text { Deconstruction \& } \\
\text { Description }\end{array}$} \\
\hline $\begin{array}{l}\text { 1) Syntactic } \\
\text { JATMIKA }\end{array}$ & $\begin{array}{l}\text { INTRODUCTION } \\
\text { ACTIVITIES } \\
\text { The teacher conditions the } \\
\text { atmosphere of a pleasant } \\
\text { learning, doing apperception, } \\
\text { informing the pattern of the } \\
\text { class JATMIKA, conveying }\end{array}$ \\
\hline
\end{tabular}

\begin{tabular}{|c|c|}
\hline & $\begin{array}{l}\text { the competencies to be } \\
\text { achieved, the outline of the } \\
\text { material and assessment. }\end{array}$ \\
\hline Core Activities & $\begin{array}{c}\text { Example Questions for } \\
\text { Measuring Indicators }\end{array}$ \\
\hline - Critical-Trace & $\begin{array}{l}\text { What type of text? What is the } \\
\text { proof? What are its } \\
\text { characteristics? }\end{array}$ \\
\hline $\begin{array}{r}\text { - Critical- } \\
\text { Analogy }\end{array}$ & $\begin{array}{l}\text { What is the text category? } \\
\text { What are its characteristics? } \\
\text { What is the difference } \\
\text { between this text and other } \\
\text { texts? Why is this text better? }\end{array}$ \\
\hline $\begin{array}{l}\text { - Transcendental- } \\
\text { Critical }\end{array}$ & $\begin{array}{l}\text { What if I change the shape of } \\
\text { the text? What if character A } \\
\text { doesn't behave like that? What } \\
\text { happens if the opposite? What } \\
\text { is your conclusion? }\end{array}$ \\
\hline $\begin{array}{l}\text { Multi-Critical } \\
\text { Interpretation }\end{array}$ & $\begin{array}{l}\text { What is the text if viewed } \\
\text { from a structural, sociological, } \\
\text { psychological, semiotic, etc. } \\
\text { perspective? }\end{array}$ \\
\hline $\begin{array}{l}\text { Intertextual- } \\
\text { Critical }\end{array}$ & $\begin{array}{l}\text { Are there text links with other } \\
\text { texts? Why related? What are } \\
\text { the connections in what ways? } \\
\text { What are the characteristics of } \\
\text { each text? }\end{array}$ \\
\hline $\begin{array}{l}\text { Critical- } \\
\text { Complexity }\end{array}$ & $\begin{array}{l}\text { What is the sign system in the } \\
\text { text? How to identify text? } \\
\text { What if the text is reviewed in } \\
\text { terms of N? How are the } \\
\text { intrinsic and extrinsic } \\
\text { elements of the text } \\
\text { translated? How do you } \\
\text { conclude about the contents of } \\
\text { the text? }\end{array}$ \\
\hline $\begin{array}{l}\text { - } \\
\text { Critical } \\
\text { Aporia }\end{array}$ & $\begin{array}{l}\text { How do you respond about the } \\
\text { weakness of the text? Is there } \\
\text { any contention in the text? }\end{array}$ \\
\hline & $\begin{array}{l}\text { CLOSING ACTIVITIES } \\
\text { The teacher and the students } \\
\text { reflect on the learning that has } \\
\text { been done and continue to } \\
\text { work on formative assessment. } \\
\text { The learning activity ends } \\
\text { with the assignment and } \\
\text { further material information. }\end{array}$ \\
\hline 2) Social system & $\begin{array}{l}\text { This model can be done in } \\
\text { receptive appreciation learning } \\
\text { by thinking individually or in } \\
\text { groups. }\end{array}$ \\
\hline $\begin{array}{l}\text { 3) Teacher Roles } \\
\text { / Tasks }\end{array}$ & $\begin{array}{l}\text { The teacher arranges the } \\
\text { stages of learning by opening } \\
\text { the students' creativity in } \\
\text { responding to develop ideas } \\
\text { and thoughts openly, } \\
\text { critically, expressively, } \\
\text { creatively, and respecting } \\
\text { irrationality. }\end{array}$ \\
\hline $\begin{array}{l}\text { 4) Supporting } \\
\text { System }\end{array}$ & $\begin{array}{l}\text { Learners need raw data for } \\
\text { dialogue and analysis through }\end{array}$ \\
\hline
\end{tabular}




\begin{tabular}{|l|l|}
\hline & $\begin{array}{l}\text { written text and online. The } \\
\text { teacher's task is to direct } \\
\text { students to process the data in } \\
\text { more complex ways. }\end{array}$ \\
\hline 5) Impact of & $\begin{array}{l}\text { This model is designed to train } \\
\text { students to think critically and } \\
\text { Accompanime } \\
\text { nt }\end{array}$ \\
& $\begin{array}{l}\text { emphatively. This model also } \\
\text { environment the social } \\
\text { students to function the } \\
\text { metaphorical } \\
\text { individually or in groups. }\end{array}$ \\
\hline
\end{tabular}

The implementation of this JATMIKA class invites students to actively seek and develop their imagination through semiotic understanding. In the context of receptive appreciation, students are free to develop their talents and potential to cultivate and appreciate literary works, while in productive appreciation of the syntax of this learning class, it is expected to produce creative and contemporary literary works.

\section{2) KARTIKA Class}

The characteristics of classroom learning "KARTIKA" invites students to be able to analyze a variety of varied texts critically, creatively, and innovatively. The learning steps are as follows.

\begin{tabular}{|c|c|}
\hline $\begin{array}{c}\text { The Design Phase of } \\
\text { the Model } \\
\text { Development }\end{array}$ & $\begin{array}{l}\text { Steps for Critical } \\
\text { Deconstruction \& } \\
\text { Description }\end{array}$ \\
\hline $\begin{array}{l}\text { 1) Syntactic } \\
\text { "KARTIKA " }\end{array}$ & $\begin{array}{l}\text { INTRODUCTION } \\
\text { ACTIVITIES } \\
\text { The teacher conditions the } \\
\text { atmosphere of a pleasant } \\
\text { learning, doing apperception, } \\
\text { informing the pattern of the } \\
\text { class "KARTIKA", conveying } \\
\text { the competencies to be } \\
\text { achieved, the outline of the } \\
\text { material and assessment. }\end{array}$ \\
\hline Core Activities & $\begin{array}{c}\text { Example Questions for } \\
\text { Measuring Indicators }\end{array}$ \\
\hline $\begin{array}{l}\text { - Critical- } \\
\text { complexity }\end{array}$ & same as above \\
\hline $\begin{array}{ll}\text { - } & \text { Critical } \\
& \text { Ambiguity }\end{array}$ & $\begin{array}{l}\text { What is the grouping of text } \\
\text { types? What is the meaning or } \\
\text { content of the text? Why are } \\
\text { your opinions different from } \\
\text { your friends? }\end{array}$ \\
\hline $\begin{array}{ll}\text { - } & \text { Critical } \\
\text { Representation }\end{array}$ & $\begin{array}{l}\text { What are the categories and } \\
\text { classifications of texts? } \\
\text { Meaning represents what } \\
\text { object, reality or } \\
\text { phenomenon? What is the } \\
\text { proof? Why represent? }\end{array}$ \\
\hline $\begin{array}{ll}\text { - } & \text { Transcendental- } \\
\text { Critical } \\
\end{array}$ & same as above \\
\hline $\begin{array}{ll} & \text { Intertextual- } \\
& \text { Critical }\end{array}$ & same as above \\
\hline
\end{tabular}

\begin{tabular}{|c|c|c|}
\hline & $\begin{array}{l}\text { Contextual- } \\
\text { Critical }\end{array}$ & $\begin{array}{l}\text { What context or environment } \\
\text { are described in the text? Why } \\
\text { is that context raised in the } \\
\text { text? What if the context is } \\
\text { replaced by another? }\end{array}$ \\
\hline \multirow{2}{*}{\multicolumn{2}{|c|}{ - Critical Aporia }} & same as above \\
\hline & & $\begin{array}{l}\text { CLOSING ACTIVITIES } \\
\text { The teacher and the students } \\
\text { reflect on the learning that has } \\
\text { been done and continue to } \\
\text { work on formative } \\
\text { assessment. }\end{array}$ \\
\hline & Social system & $\begin{array}{l}\text { This model can be done by } \\
\text { arranging individual or group } \\
\text { classes. Learning material can } \\
\text { be in the form of literary } \\
\text { theory or literary appreciation. }\end{array}$ \\
\hline & $\begin{array}{l}\text { Teacher Roles / } \\
\text { Tasks }\end{array}$ & $\begin{array}{l}\text { The teacher encourages } \\
\text { students to develop open } \\
\text { thinking, irrationality, and } \\
\text { critical and creative } \\
\text { expression }\end{array}$ \\
\hline & $\begin{array}{l}\text { Supporting } \\
\text { System }\end{array}$ & $\begin{array}{l}\text { Learners need data from } \\
\text { various sources to be } \\
\text { analyzed, both in the form of } \\
\text { written text and oral text. } \\
\text { Integrated learning based on } \\
\text { "blanded learning" will make } \\
\text { students more creative and } \\
\text { independent. }\end{array}$ \\
\hline & $\begin{array}{l}\text { Impact of } \\
\text { Learning and } \\
\text { Accompaniment }\end{array}$ & $\begin{array}{l}\text { This model also emphasizes } \\
\text { the social environment that } \\
\text { allows students to function the } \\
\text { metaphorical world } \\
\text { individually or in groups. }\end{array}$ \\
\hline
\end{tabular}

Like its symbolic meaning, the KARTIKA class will provide an energetic atmosphere in the literature appreciation class. Students are given freedom of expression through complex and contradictory thoughts in analyzing the relationship between one text and another.

\section{CONCLUSION}

Deconstruction thinking is always based on critical thinking, but in its implementation, it will depend on one's competency. Derrida's deconstruction of thought is a way of reading and interpreting something to find new meanings outside their textual meanings. Derrida's deconstruction is actually a useful practice in uncovering hidden meanings and perceptions in the text in a style of interpretation that sometimes leads to finding out unexpected meanings. Deconstruction is indeed intended to uncover hidden meanings and other implied, not just explicit meanings.

The results of theoretical studies show that "all deconstruction is critical", but what needs to be studied further is that critical thinking has not reached all elements perfectly but there must be weaknesses. Critical thinking of each person varies according to their respective competencies. The success of the learning process with this critical deconstruction thinking model will be influenced by 
several other factors, such as age, gender, learning styles and teaching in general school education.

The application of critical deconstruction thinking is carried out for literary appreciation activities. Appreciators receptively deconstruct critical discourse and language texts and productively produce creative works that are different from those that already exist. The application of critical deconstruction thinking is carried out for literary appreciation activities. Appreciators receptively deconstruct critical discourse and language texts and productively produce creative works that are different from those that already exist. Basically, the development of this model aims to invite lecturers/teachers to dare to break through the steps of conventional learning in new ways that are more creative

\section{REFERENCES}

Afsahi, Sayed Ehsan dan Afghari, Akbar. (2017). The Relationship between Mother Tongue, Age, Gender and Critical Thinking Level. Journal of Applied Linguistics and Language Research. Volume 4 Issue 1, 2017, pp. 116-124 Available online at www.jallr.com ISSN: 2376-760X

Al-Fayyad, Muhammad. (2005). Derrida. Yogyakarta: LKiS.

Derrida, Jacques. (1997). Of Grammatology. (Translated by Gayatri Chakravorty Spivak). London: The Johns Hopkins University Press. (1982). Positions. Chicago: The University of Chicago Press (1978). Writing and Difference. London and Henley: Routledge \& Kegan Paul Ltd, Press.

. (1973). Speech and Phenomena. USA: Nortwestern University

Dileklii, Yalçin. (2017). The Relationships Between Critical Thinking Skills And Learning Styles Of Gifted Students. European Journal of Education Studies, Volume 3, Issue 4, 2017. ISSN: 2501 - 1111 ISSNL: 2501 - 1111 Available on-line at (p.69-96). Accessed from: oapub.org/edu/index.php/ejes/article/view/552. March 8, 2019.

Effendi. (2002). Apresiasi Sastra. Jakarta. Pustaka Jaya.

Facione, Peter A. (2011). What It Is and Why It Counts. Insight Assessment. Millbrae, CA: Measured Reasons and The California Academic Press. By phone at $650-697-5628$ or by email to jmorante@insightassessment.com. ISBN 13: 978-1-891557-07-1

(1990a). Critical Thinking: A Statement of Expert Consensus for

Purposes of Educational Assessment and Instruction. American Philosophical Association, Newark, Del, 90. Accessed from: https://files.eric.ed.gov/fulltext/ED315423.pdf April 8, 2019.

Facione, Peter A \& Facione, Noreen C. (2013). Critical Thinking for Life Valuing, Measuring, and Training Critical Thinking in All Its Forms. Spring-Inquiry: Critical Thinking Across The Disciplines, VoL. 28 , NO. 1. Publishing: Measured Reasons, Hermosa Beach, CA

Gnanasekaran, R. (2015). An Introduction to Derrida, Deconstruction and Post-Structuralism. International Journal of English Literature and Culture. Vol. 3(7), pp. 211-214, July 2015 ISSN: 2360-7831 Accessed from:

http://www.academicresearchjournals.org/IJELC/Index.htm.April 8 2019. and innovative. Critical thinking through this kind of critical literacy makes students have an open-minded habitus, open thinking about other inputs, the basics of other arguments and that turns out to be good too and is very true also when humans become open to other thoughts as well as paradigms the paradigm he wears. Critical thinking through this kind of critical literacy makes students have an open-minded habitus, open thinking about other inputs, the basics of other arguments and that turns out to be good too and is very true also when humans become open to other thoughts as well as paradigms the paradigm he wears.

Gregory, Anne M. and Cahil,Mary Ann. (2009). Constructing Critical Literacy: Self-reflexive ways for curriculum and pedagogy. Critical Literacy: Theories and Practices Vol.3 Idaho: Boise State University, USA.

Hoteit, Aida. (2015). Deconstructivism: Translation From Philosophy to Architecture. Canadian Social Science. Vol. 11, No. 7, 2015, pp. 117 129. DOI: 10.3968/7240. ISSN 1923-6697[Online] www.cscanada.net

Hussin, Wan Nur Tasnim Wan, et.al. (2019). Online Interaction In Social Learning Environment Towards Critical Thinking Skill: A Framework. Journal of Technology and Science Education (JOTSE), 2019 - 9(1): 4-12 - Online ISSN: 2013-6374 - Print ISSN: 2014-5349 https://doi.org/10.3926/jotse.544

Joyce, Bruce \& Well, Marsha, and Calhoun,Emily. (2009). Models of Teaching, 8th ed. Jakarta: Pustaka Pelajar.

Nuryatin, Agus \& Irawati, Purnama Irawati. (2016). Pembelajaran Menulis Cerpen. Semarang: Cipta Prima Nusantara.

Oemarjati, Boen S. (1996). Pengajaran Sastra Mencerdaskan Murid Memperkaya Pengalaman dan Pengetahuan. Berbagai Pendekatan dalam Pengajaran Bahasa dan Sastra. Ed. Mulyanto Sumardi. Jakarta: Midas Karya Grafindo.

Rahimi, Ali and Sajed, Mina Asadi. (2014). The Interplay between Critical Pedagogy and Critical Thingking: Theoritical and Practicalities. Elsevier: Social and Behavioral Sciences. WWW.sciencedirect.com

Royle, Nicholas. (2003). Jacques Derrida. London and New York: Routledge is an imprint of the Taylor \& Francis Group

Sarup, Madan. (2008). Panduan Pengantar untuk Memahami Postrukturalisme \& Posmodernisme. Yogyakarta: Jalasutra.

(1993). An Introductory Guide to Post-Structuralism and Postmodernism. Published 1993 by University of Georgia Press. Accessed from: https://epdf.tips/queue/introductory-guide-to-poststructuralism-and-postmodernism.html. April 24, 2019.

Wallace, Elise D. dan Jefferson, Renee N. (2013). Developing Critical Thinking Skills For Information Seeking Success. New Review of Academic Librarianship. Published with license by Taylor \& Francis Volume 19:246-255, 2013. ISSN: 1361-4533 online. DOI:10.1080/13614533.2013.802702.

Yegen, Ceren dan Abukan, Memet. (2014). Derrida and Language: Deconstruction. International Journal of Linguistics - ISSN 19485425-2014, Vol. 6, no.2 URL: http://dx.doi.org/10.5296/ijl.v6i2.5210. Marc 8, 2019 